Vitaly Gulyaev ${ }^{1}$, Vadim Barsky² and Natalya Gurevina ${ }^{2}$

\title{
EFFECT OF TOTAL ASH CONTENT AND COALS ASH COMPOSITION ON COKE REACTIVITY
}

\author{
${ }^{1}$ Dneprodzerginsk State Technical University, Ukraine \\ ${ }^{2}$ Ukrainian State Chemico-Technological University, Dnepropetrovsk, Ukraine
}

Received: April 03, 2009

(C) Gulyaev V., Barsky V., Gurevina N., 2009

\begin{abstract}
The article deals with the hypothesis of the influence of coals mineral components on coke reactivity. It has been shown that the reaction between carbon and carbon dioxide proceeds in kinetic area and its rate depends upon total ash content of coked coal. The data showing catalyst effect of coal mineral components upon their organic mass pyrolysis and consequently upon coke reactivity have been presented.
\end{abstract}

Keywords: reactivity, coke, coal, ash.

\section{Introduction}

Numerous publications on coke reactivity $(\mathrm{CR})$ deal with the discussions of the influence of mineral components of coal, coal charges and, consequently, coke upon coke gasification reaction [1-3]. Moreover, analyzing this influence one can categorize ash components into catalysts activating and inhibiting the interaction reaction between carbon and carbon dioxide [1] or the ones accelerating (promoter of positive catalysis) and inhibiting (inhibitors of negative catalysis) this reaction [2-3].

As the result, there exists a wide-spread use of the basicity index [4] as the relation between total content of substances with different acid-base properties:

$$
I_{0}=\frac{\mathrm{Fe}_{2} \mathrm{O}_{3}+\mathrm{CaO}+\mathrm{MgO}+\mathrm{Na}_{2} \mathrm{O}+\mathrm{K}_{2} \mathrm{O}}{\mathrm{SiO}_{2}+\mathrm{Al}_{2} \mathrm{O}_{3}}
$$

or, with respect to ash content of coke:

$$
I=\frac{100 \cdot A_{y}^{d}}{100-V_{y}^{d a f}} \cdot I_{0}
$$

where $A_{y}^{d}$ and $V_{y}^{d a f}$ are ash content in coal and volatile substance yield, mas $\%$.

Despite the plenty of various regression equations in such publications, the obtained results are incomplete. Moreover, there are no sufficient reasons to connect the catalytic action of mineral components only with the stage of coke gasification; most probably the catalyst effect of these substances will become evident during pyrolysis of coals and coal charges [5,6]. Therefore, the system analysis of the problem concerning the coal mineral components effect is assumed to be necessary. The mentioned analysis includes the estimation as following:

1. The effect of total mineral content in coal $A_{y}^{d}$ and content of "ash" changing with its reduction upon the main characteristics of coals properties $\left(y, V^{\text {daf }}, L^{\text {daf }}\right)$ and coke (its mineral part content and CR).

2. The effect of variable mineral content of coal upon these parameters at constant total ash content.

\section{Experimental}

For the analysis of point 1 (exp. 1) we used experimental data from [1]. By their physicochemical properties investigated coals were similar to eastern coals of KG brand from the "Shakhtinskaya" and "Stepnaya" mines, which were cleaned in dense media with zinc chloride solution density of $1200-1600 \mathrm{~kg} / \mathrm{m}^{3}$.

For the analysis of point 2 (exp. 2) the experimental results from work [4] were used. The data were obtained during charges coking mainly from Ukrainian coals of different brands cleaned to almost similar ash content. The peculiarity of this experiment is minor spread in values of charges ash content (7.7-8.3 mas \%) with considerable differences between their mineral compositions.

Table 1 presents average values of coals and charges ash content and its components, the units for the spread of these parameters values being absolute $\left(S_{y}\right)$ and relative $\left(S_{y} \cdot 100 / \bar{y}\right)$ :

1. The size of total ash content changing in experiment 1 is almost 14 times greater than the size of changing $A_{y}^{d}$ in experiment 2 , thus, we should use the data from experiment 1 for the estimation of total ash content effect.

2. The average contents of $\mathrm{SiO}_{2}$ in these experiments agree in values while the contents of $\mathrm{Al}_{2} \mathrm{O}_{3}$ and $\mathrm{Fe}_{2} \mathrm{O}_{3}$ are 
Comparative data on coals and coal charge ash content and its composition

\begin{tabular}{|c|c|c|c|c|c|c|}
\hline \multirow{2}{*}{ Component } & \multicolumn{2}{|c|}{$\bar{y}$, mas $\%$} & \multicolumn{2}{|c|}{$S_{y}$, mas \% } & \multicolumn{2}{|c|}{$S_{y} \cdot 100 / \bar{y}$, rel. $\%$} \\
\hline & exp. 1 & exp. 2 & exp. 1 & exp. 2 & exp. 1 & exp. 2 \\
\hline$A_{y}^{d}$ & 8.15 & 8.06 & 2.12 & 0.15 & 26.01 & 1.86 \\
\hline $\mathrm{SiO}_{2}$ & 45.24 & 44.09 & 1.38 & 2.09 & 3.05 & 4.75 \\
\hline $\mathrm{Al}_{2} \mathrm{O}_{3}$ & 34.73 & 26.62 & 1.56 & 1.15 & 4.49 & 4.33 \\
\hline $\mathrm{TiO}_{2}$ & 1.90 & - & 0.22 & - & 11.80 & - \\
\hline $\mathrm{Fe}_{2} \mathrm{O}_{3}$ & 7.34 & 17.01 & 0.53 & 2.86 & 7.24 & 16.80 \\
\hline $\mathrm{MgO}$ & \multirow{2}{*}{5.84} & 1.58 & \multirow{2}{*}{0.60} & 0.13 & \multirow{2}{*}{10.20} & 8.19 \\
\hline $\mathrm{CaO}$ & & 3.66 & & 0.27 & & 7.38 \\
\hline $\mathrm{Na}_{2} \mathrm{O}$ & \multirow{2}{*}{2.41} & 1.21 & \multirow{2}{*}{0.58} & 0.08 & \multirow{2}{*}{24.25} & 6.51 \\
\hline $\mathrm{K}_{2} \mathrm{O}$ & & 1.62 & & 0.14 & & 8.61 \\
\hline $\mathrm{P}_{2} \mathrm{O}_{5}$ & 1.16 & - & 0.14 & - & 11.80 & - \\
\hline $\mathrm{SO}_{3}$ & - & 1.97 & - & 0.20 & - & 10.21 \\
\hline $\mathrm{S}$ (total) & 1.46 & - & 0.40 & - & 27.41 & - \\
\hline
\end{tabular}

considerably different: eastern coals contain almost 10 mas \% more of $\mathrm{Al}_{2} \mathrm{O}_{3}$ and almost the same value less $\mathrm{Fe}_{2} \mathrm{O}_{3}$ than the Ukrainian ones.

These data show that $\mathrm{Al}_{2} \mathrm{O}_{3}$ of eastern coals is related to internal (parent) component, and $\mathrm{Fe}_{2} \mathrm{O}_{3}$ - to external mineral components which are easily removed during the cleaning process.

For Ukrainian coals there is another regularity: $\mathrm{Fe}_{2} \mathrm{O}_{3}$ relates to internal mineral components resulting in its hard removal during the cleaning process while $\mathrm{Al}_{2} \mathrm{O}_{3}$ (here is an external component) is readily removed.

3. Despite a very narrow range of $A_{y}^{d}$ changes in exp. 2, its mineral components content change region is commensurable with the similar regions in exp. 1, but regarding $\mathrm{Fe}_{2} \mathrm{O}_{3}$ it is 5.4 times greater with respect to $S_{y}$ and 2.32 times greater with respect to relative values.

\section{Results and Discussion}

According to the data of exp. 1 (coals from the "Shakhtinskaya" and "Stepnaya" mines) we investigated relations of total ash content and mineral component composition for coals with different degrees of cleaning and obtained coke.

Proceeding from general considerations, according to which the ash content in coke is determined by the content of ash components and thermochemical transformations of coals organic mass accompanied by formation of vapor gases, the relation between mentioned parameters is as follows:

$$
A_{k}^{d}=\frac{100}{100-V^{d a f}} \cdot A_{y}^{d} .
$$

In practical description of this relation there are also possible transformations of coals and coke mineral components during coking and determination of $A_{y}^{d}$ and $A_{k}^{d}$ values.

The data in Fig. 1 show that the average yield of volatile substances in coals is $V^{\text {daf }}=21.41$ mas \% which are in agreement with actual values. Due to the reduction of coked substance mass corresponding to yield of volatile substances, ash content of coke changes by 1.29 mas \% (not by 1 mas \%) with the change of coal ash content by 1 mas $\%$.

The free member of equation shown in Fig.1 estimates changes of coke ash content caused by transformations of mineral components of coal "ash".

Similarly we investigated dependences between the content of the same mineral components in coals and cokes ash. The content of these components changes

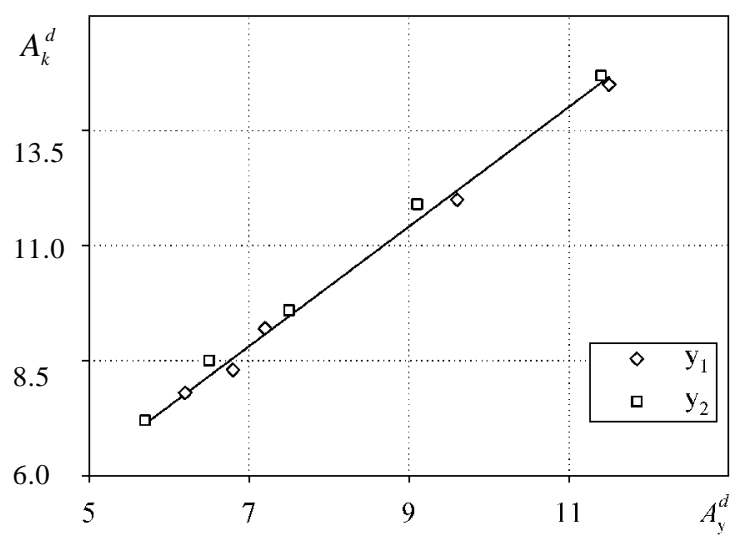

Fig. 1. Dependence of $A_{x}^{d}$ upon $A_{y}^{d}$ : $\left(A_{\kappa}^{d}=-0.14+1.29 A_{y}^{d} ; r_{x y}=0.997 ; \mathrm{S}_{\mathrm{res}}=0.196\right.$; $\overline{A_{y}}=8.15 ; \dot{A}_{\kappa}^{x y}=10.37$ ) 


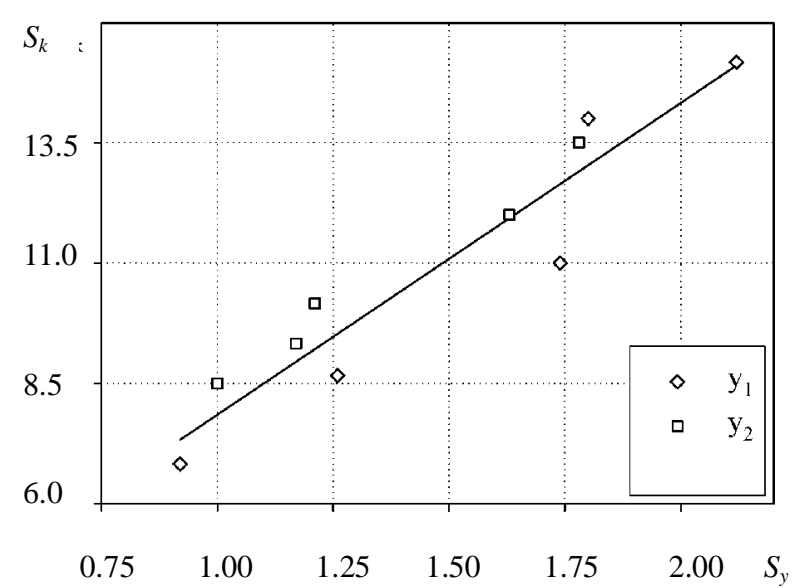

Fig. 2. Dependence between sulfur content in coal and coke: $S_{k}=0.124+0.390 S_{y} ; r_{x y}=0.950$; $S_{\text {res }}=0.048 ; S_{y}=1.463 ; S_{k}=0.695$

directly proportionally to each other. At the same time during transition from coal to coke the content of $\mathrm{SiO}_{2}$, $\mathrm{Al}_{2} \mathrm{O}_{3}, \quad\left(\mathrm{Na}_{2} \mathrm{O}+\mathrm{K}_{2} \mathrm{O}\right)$ increases, $\quad \mathrm{TiO}_{2}, \quad \mathrm{Fe}_{2} \mathrm{O}_{3}$, $(\mathrm{CaO}+\mathrm{MgO}), \mathrm{P}_{2} \mathrm{O}_{5}$ have slight changes, $\mathrm{S}$ reduces more than twice (see Fig. 2).

The latter can be explained by the fact that the most part of sulfur-containing compounds in coals are presented as $\mathrm{CaSO}_{4}$ and $\mathrm{Fe}_{2}\left(\mathrm{SO}_{4}\right)_{3}$ which can decompose by the reactions (4) and (5):

$$
\begin{gathered}
\mathrm{CaSO}_{4} \leftrightarrow \mathrm{CaO}+\mathrm{SO}_{3} \\
\mathrm{Fe}_{2}\left(\mathrm{SO}_{4}\right)_{3} \leftrightarrow \mathrm{Fe}_{2} \mathrm{O}_{3}+3 \mathrm{SO}_{3} .
\end{gathered}
$$

The released gaseous $\mathrm{SO}_{3}$ leaves the pyrolysis zone with volatile products of the coking process which determines such a sharp drop in sulfur content during transition from coal to coke.

One can see from the results of thermodynamic calculation (Fig. 3a) the proceeding of the reaction (4) towards the formation of $\mathrm{SO}_{3}$ is impossible within the temperature range of the cocking process. At the same time, thermochemical transformation of $\mathrm{Fe}_{2}\left(\mathrm{SO}_{4}\right)_{3}$ with formation of $\mathrm{Fe}_{2} \mathrm{O}_{3}$ and $\mathrm{SO}_{3}$ at temperatures above $960 \mathrm{~K}$ is thermodynamically possible and this possibility increases with the temperature increase (see Fig. 3b).

For additional substantiation of the hypothesis on $\mathrm{Fe}_{2} \mathrm{O}_{3}$ and $\mathrm{SO}_{3}$ formation from $\mathrm{Fe}_{2}\left(\mathrm{SO}_{4}\right)_{3}$ we proceed from the fact that the products yield of the same reaction should be interconnected by a sufficiently close linear dependence, which is proved by the data shown in Fig. 4.

The obtained results are sufficient for excluding the yield and content of coke ash as intermediate values which do not give us more useful information. In this connection taking into consideration the data of exp. 1 (eastern coals) we investigated the dependence of CR upon
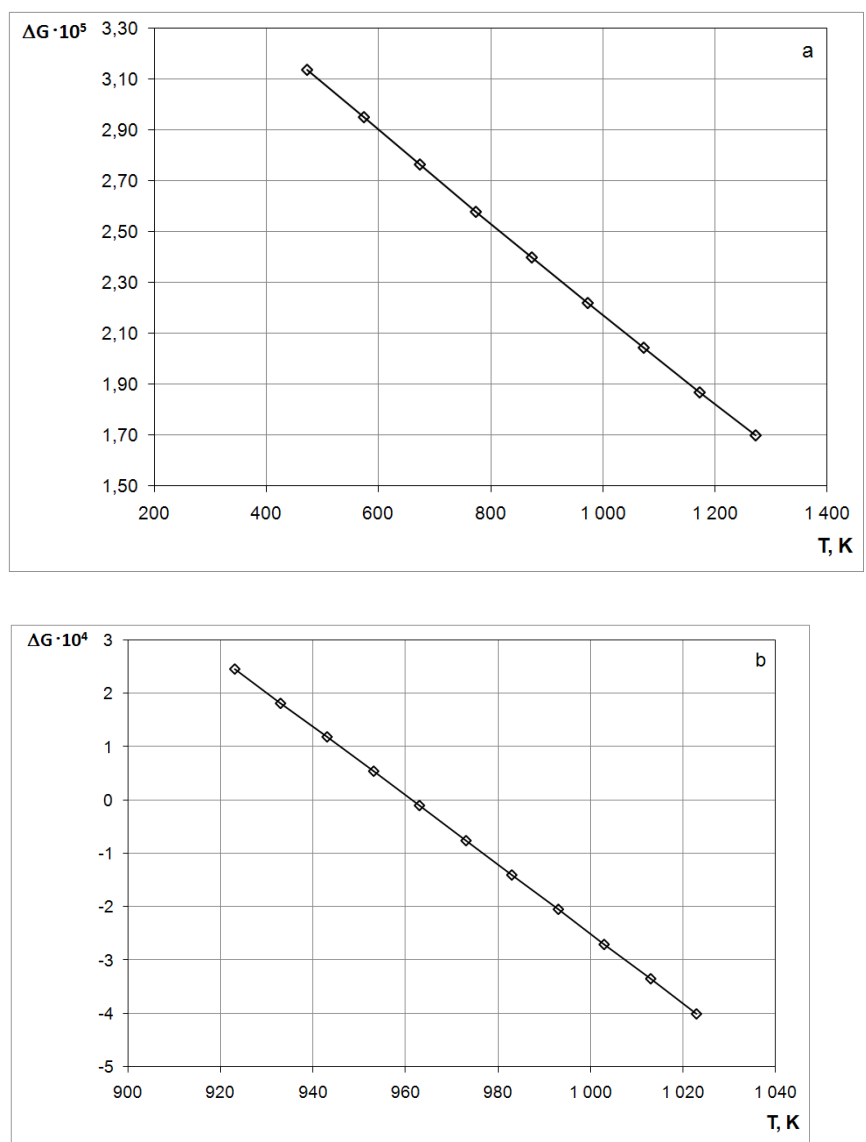

Fig. 3. Temperature dependence of Gibbs energy $(\Delta G)$ : for the reaction (4) (a) and for the reaction (5) (b)

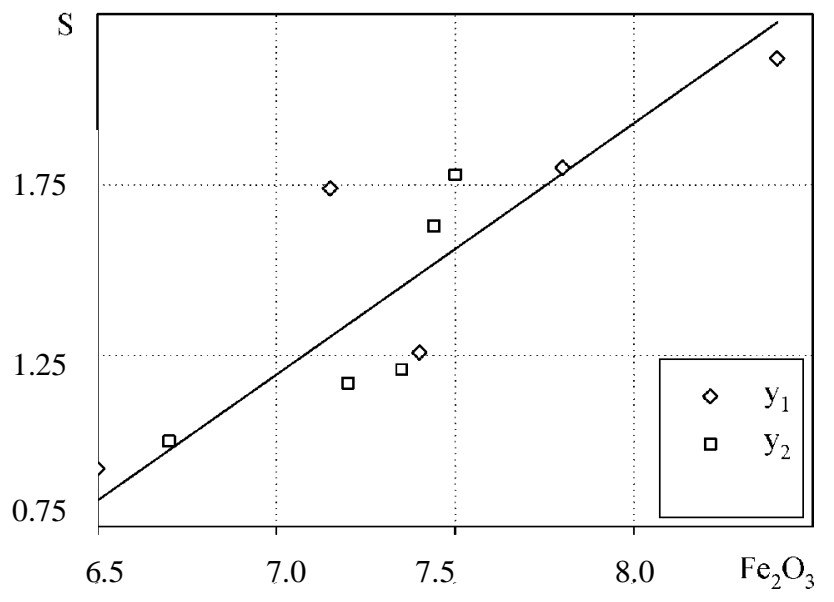

Fig. 4. Dependence of sulfur content upon $\mathrm{Fe}_{2} \mathrm{O}_{3}$ in coal ash: $S=-3.833+0.721 \mathrm{Fe}_{2} \mathrm{O}_{3} ; r_{x y}=0.853 ; S_{r e s}=0.196$

total ash content of coals. CR represented a rate constant $K$ of coke gasification reaction, determined at the temperatures 1223,1273 and $1323 \mathrm{~K}$ using impulse method [8].

Despite high probabilistic estimation of obtained equations (see Figs. 5a, 5b and 5c), it is obvious that parameters of true dependence of $K$ upon $A^{d}$ are different for coals from the mines "Shakhtinskaya" $\left(y_{1}\right)$ and 


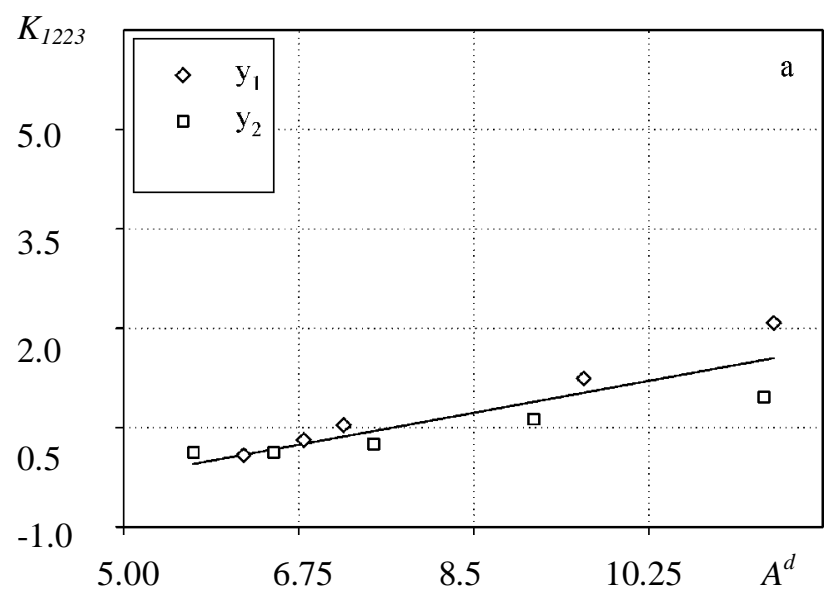

Fig. 5a Dependence of $\mathrm{CR}$ on coal ash content (gasification at $1223 \mathrm{~K}$ ): $K_{1223}=-1.559+0.269 A^{d} ; r_{x y}=0.882$; $S_{\text {res }}=0.283$

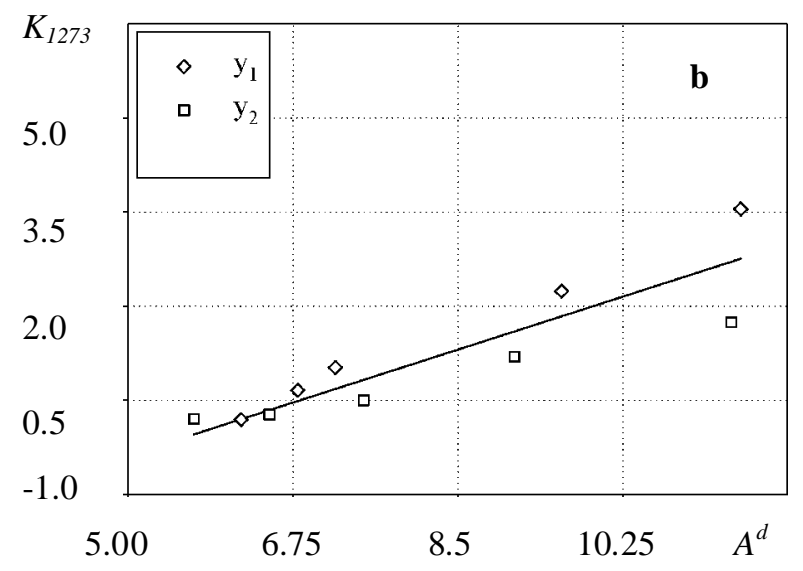

Fig. 5b Dependence of $\mathrm{CR}$ on coal ash content (gasification at $1273 \mathrm{~K}): K_{1273}=-2.729+0.477 A^{d} ; r_{x y}=0.892 ; S_{r e s}=0.463$

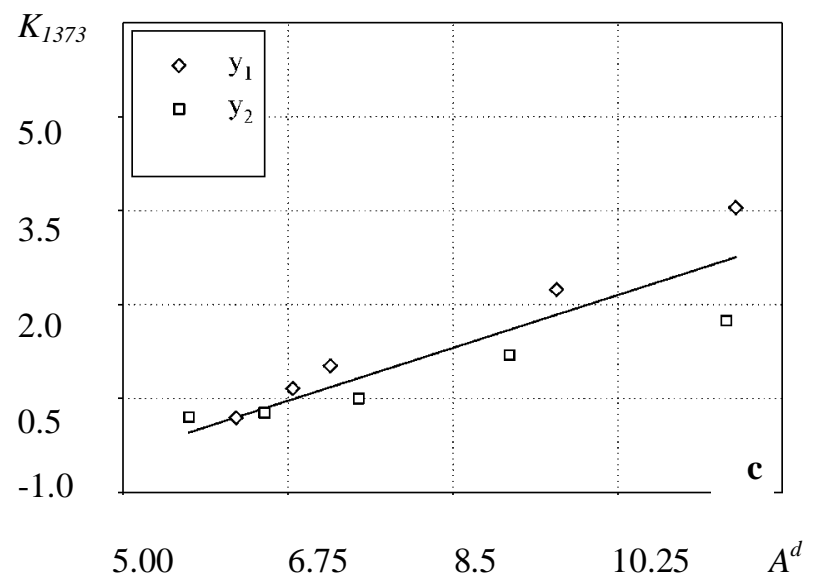

Fig. 5c Dependence of $\mathrm{CR}$ on coal ash content (gasification at $1323 \mathrm{~K}): K_{1323}=-4.719+0.841 A^{d} ; r_{x y}=0.897 ; S_{r e s}=0.756$
"Stepnaya" $\left(y_{2}\right)$. Moreover these differences increase with the increase of gasification temperature but in all cases cokes from the mine "Shakhtinskaya" coals show higher CR.

Then the dependences for each coal were shown by equations of the following type:

$$
K_{t}=b_{0}+b_{1} \cdot A^{d}
$$

Coefficients and statistic parameters of these equations are shown in Table 2 .

The Eq. (6) shows that condition $K_{t}=0$ is achieved at $A_{0}^{d}=-\frac{b_{0}}{b_{1}}$. It means that at coal cleaning to the value $A^{d} \leq A_{0}^{d}$ CR of coke produced from this coal does not depend on its total ash content anymore.

Numerical estimations of $A_{0}^{d}$ for coals of the mines "Shakhtinskaya" and "Stepnaya" at different gasification temperatures are also given in Table 2.

From the obtained data we can conclude following:

1. At constant properties of coal determined by its nature and gasification reaction temperature CR is actually determined by the depth of coal cleaning $\left(0.985 \leq r_{x y} \leq 0.997\right)$.

2. Dependence of $b_{0}$ and $b_{1}$ indexes on temperature (see Table 2) shows that gasification reaction takes place in kinetic area.

3. The change of $A_{0}^{d}$ with the temperature increase is described by equations:

$$
\begin{gathered}
A_{0}^{d}\left(y_{1}\right)=10.5656-0.0038 T \\
A_{0}^{d}\left(y_{2}\right)=9.4381-0.0033 T
\end{gathered}
$$

Such small values of indexes at $T$ in (7) and (8) allow to use average values $\overline{A_{0}^{d}}\left(y_{1}\right)=5.734$ mas $\%$ and $\overline{A_{0}^{d}}\left(y_{2}\right)=5.232$ mas $\%$ as parameters in (6) allowing to exclude the free member from it.

Actually when we introduce a new variable $\hat{A}^{d}=A^{d}-\bar{A}_{0}^{d}$, we obtain (6) as $K_{t}=\left(b_{0}+b_{1} \cdot \bar{A}_{0}^{d}\right)+b_{1} \cdot \hat{A}^{d}$. Since $b_{0}+b_{1} \cdot \bar{A}_{0}^{d}=0$, we determine:

$$
K_{t}=b_{1}\left(A^{d}-\bar{A}_{0}^{d}\right)
$$

Now (9) can be as follows:

$$
K=K_{0} \cdot e^{-\frac{E}{R T}} \cdot\left(A^{d}-\bar{A}_{0}^{d}\right)
$$


Parameters of regressive dependences between CR and coals ash content

\begin{tabular}{|c|c|c|c|c|c|c|c|c|c|c|c|c|}
\hline$T, \mathrm{~K}$ & \multicolumn{4}{|c|}{1223} & \multicolumn{4}{|c|}{1273} & \multicolumn{4}{|c|}{1323} \\
\hline $\begin{array}{c}\begin{array}{c}\text { Equation } \\
\text { parameter }\end{array} \\
\text { Coal }\end{array}$ & $b_{0}$ & $b_{1}$ & $r_{x y}$ & $S_{\text {res }}$ & $b_{0}$ & $b_{1}$ & $r_{x y}$ & $S_{\text {res }}$ & $b_{0}$ & $b_{1}$ & $r_{x y}$ & $S_{\text {res }}$ \\
\hline $\begin{array}{l}\text { the mine } \\
\text { "Shakh- } \\
\text { tinskaya" } \\
\left(y_{1}\right)\end{array}$ & -2.154 & 0.364 & 0.997 & 0.059 & -3.511 & 0.611 & 0.997 & 0.088 & -5.621 & 1.015 & 0.996 & 0.169 \\
\hline $\begin{array}{l}\text { the mine } \\
\text { "Stepnaya } \\
"\left(y_{2}\right)\end{array}$ & -0.857 & 0.159 & 0.985 & 0.056 & -1.527 & 0.291 & 0.989 & 0.089 & -2.575 & 0.509 & 0.985 & 0.178 \\
\hline$A_{0}^{d}\left(y_{1}\right)$ & \multicolumn{4}{|c|}{5.918} & \multicolumn{4}{|c|}{5.746} & \multicolumn{4}{|c|}{5.538} \\
\hline$A_{0}^{d}\left(y_{2}\right)$ & \multicolumn{4}{|c|}{5.390} & \multicolumn{4}{|c|}{5.247} & \multicolumn{4}{|c|}{5.059} \\
\hline
\end{tabular}

According to the data we have the following equations:

$$
\begin{gathered}
K_{y_{1}}=283972.1957 \cdot e^{\frac{137951.9238}{8.314 T}} \cdot\left(A_{y_{1}}^{d}-5.7340\right) \\
K_{y_{2}}=770529.7811 \cdot e^{\frac{156523.3243}{8.314 T}} \cdot\left(A_{y_{2}}^{d}-5.2320\right)
\end{gathered}
$$

During verification of the equations besides estimation of random deviations of calculated values and from experimental $K_{e}\left(r_{x y}, S_{\text {res }}\right)$ we estimated the value of possible systematic deviation which would demonstrate the existence of unaccounted drastic factor.

Proceeding from the hypothesis of the such a factor absence we believed that the relation between experimental $K_{e}$ and $K_{y}$ values calculated by (11)-(12) is described by the linear equation

$$
K_{y}=b_{0}+b_{1} \cdot K_{e},
$$

where $b_{0}=0$ and $b_{1}=1$.

Fig. 6 represents experimental and calculated results of 30 experiments for 2 coals presented by 5 levels of cleaning depth for each, with 10 coking processes in 25kilograms furnace with the load density of $750 \mathrm{~kg} / \mathrm{m}^{3}$, the constant rate of temperature increase to $1073 \mathrm{~K}$ along the load axis and determination of $\mathrm{CR}$ at three temperatures of coke gasification.

The obtained results show adequacy of dependences (11) and (12). At the same time the investigated coals have almost 2 -fold difference in the value of rate constant for coke gasification reaction ( $\bar{K}_{y_{1}}=1.729$ and $\bar{K}_{y_{2}}=0.905$ ).

While searching for parameters of coals properties, which difference in values leads to different coefficients in Eqs. (11) and (12), we considered the most important parameters of their plastic state: width of plastic layer and liquid phase yield during coking in a centrifugal field. As

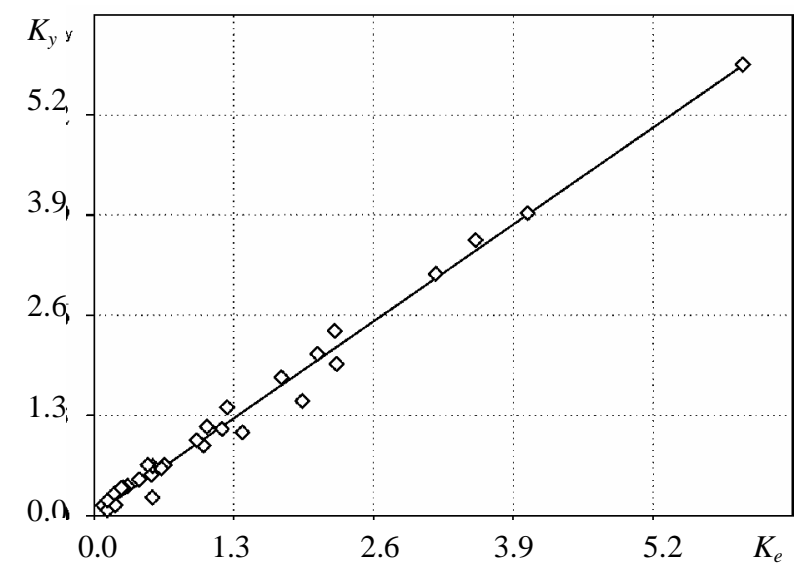

Fig. 6. Dependence between calculated by Eqs. $(11,12)$ and experimental values of CR: $K_{y}=0.0190+0.9700 \cdot K_{e}$; $r_{x y}=0.9700 ; S_{r e s}^{y}=0.1420$

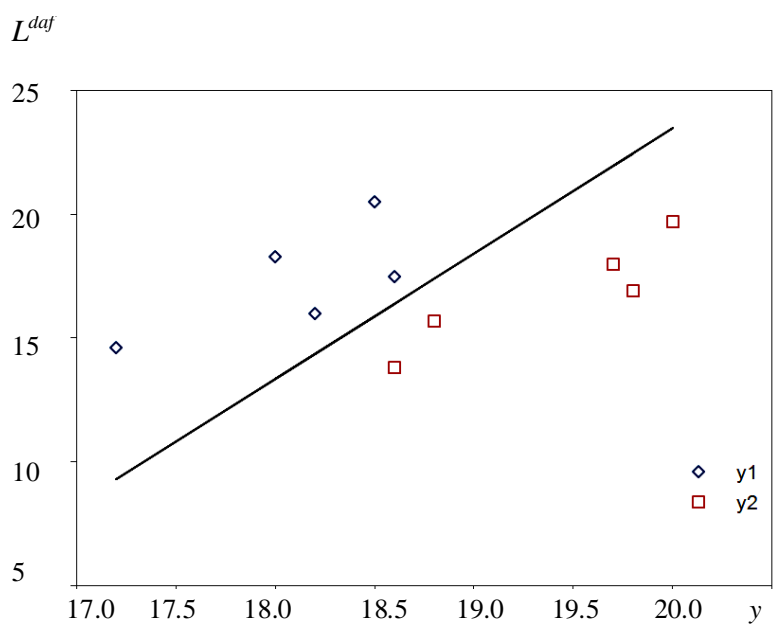

Fig. 7. Dependence between parameters of coals plastic mass $y$ and $L^{\text {daf }}$ 


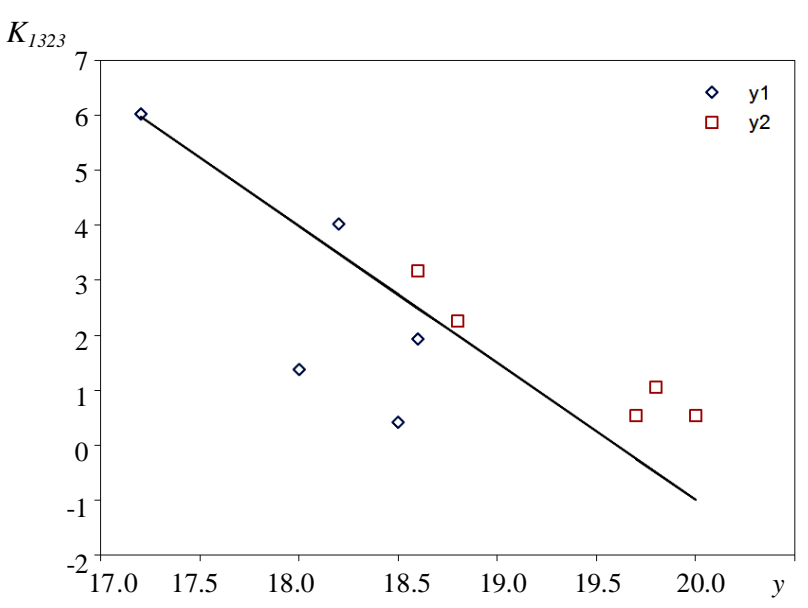

Fig. 8. Dependence between CR with respect to $K_{1323}$ and

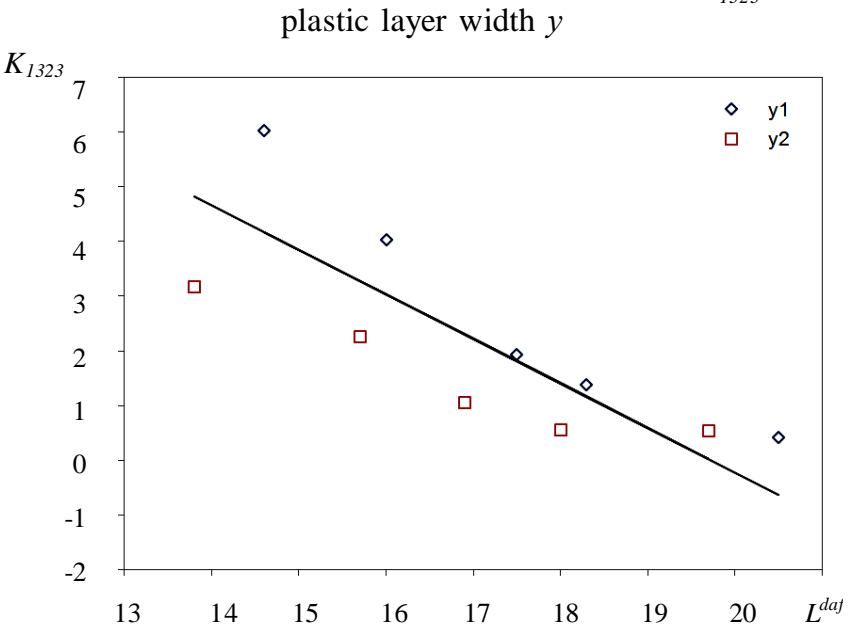

Fig. 9. Dependence between $\mathrm{CR}$ with respect to $K_{1323}$ and liquid phase yield $L^{\text {daf }}$

can be seen from Fig. 7, according to these parameters, the data obtained for different coals are clearly divided into two groups: coals from both mines are characterized by close value of $L^{d a f}$ but differ in parameter $y$.

It is characteristic that such grouping of data can be seen in analysis of CR dependence upon $y$ and $L^{\text {daf }}$ (see Figs. 8 and 9) which allows to assume a catalyst action of mineral components on the reaction of coal organic mass pyrolysis and as the result on CR [6].

\section{Conclusions}

Coke reactivity is determined by ash content of coke and coal charge.

Dependence of rate constant of coke gasification reaction, obtained from this coal charge, on gasification reaction temperature indicates the reaction proceeding in the kinetic area.

The obtained data are assumed to reveal that mineral components of coal charge have catalytic effect on pyrolysis reaction of coal organic mass and as a result on coke reactivity.

\section{References}

[1] Vejnskiy V. and Barskiy V.: Koks i Khimiya, 1990, 12, 9. [2] Miroshnichenko D. and Ulanovskiy M.: Koks i Khimiya, 2004, 5, 21.

[3] Kosogorov S., Kogan L, Kaufman A. and Kukolev Ya.: Koks i Khimiya, 2006, 7, 16.

[4] Kaftan Yu., Drozdnik I., Miroshnichenko D. et al.: Uglekhim. Zh., 2007, 3-4, 3.

[5] Ulanovskiy M. and Mirishnichenko D.: Uglekhim. Zh., 2005, 1-2, 49.

[6] Shkoler M.: Koks i Khimiya, 2007, 6, 2.

[7] Barskiy V., Veynskiy V. and Mikhaylova T.: Koks i Khimiya, 1990,3, 6 .

\section{ВПЛИВ ЗАГАЛЬНОЇ ЗОЛЬНОСТІ ТА СКЛАДУ ЗОЛИ ВУГІЛЛЯ НА РЕАКЦІЙНУ ЗДАТНІСТЬ КОКСУ}

Анотація. Розглядається гіпотеза про вплив мінеральних складових вугілля на реакиійну здатність коксу. Показано, шьо реакиія між вуглеием та його діоксидом протікає в кінетичній області та ї̈ швидкість залежить від загальної зольності вугілля, що коксується. Отримані дані про каталітичну дію компонентів мінеральної частини вугілля на піроліз його органічної маси $i$, як наслідок, на реакиійну здатність коксу.

Ключові слова: реакиійна здатність, кокс, вугілля, зола. 